\title{
Developing Technologies Utilization of Waste in the Context of Clean Energy Technology
}

\author{
Grzegorz Walowski \\ Department of Renewable Energy Sources, Institute of Technology and Life Sciences, Poznań Branch, Poland
}

Email address:

g.walowski@itp.edu.pl,walowski.g@gmail.com

\section{To cite this article:}

Grzegorz Wałowski. Developing Technologies Utilization of Waste in the Context of Clean Energy Technology. International Journal of Economy, Energy and Environment. Vol. 2, No. 6, 2017, pp. 109-114. doi: 10.11648/j.ijeee.20170206.14

Received: November 11, 2017; Accepted: November 20, 2017; Published: December 14, 2017

\begin{abstract}
New concepts and trends in unconventional clean energy technologies are emerging in the world economy, aimed at reducing the harmful effects of production processes, rationalizing the use of renewable fuels and raw materials and neutralizing post-production waste. The aim of this paper is to present and compare technological options for utilization of agricultural waste in methane fermentation.
\end{abstract}

Keywords: Utilization of Waste, Mono-Substrate Reactor, Clean Energy Technology

\section{Introduction}

Methane fermentation is a biological process in which methane dissolves organic matter in anaerobic conditions, and the final product of this process is biogas with $\mathrm{CH}_{4}$ content of $50-75 \%$ and $\mathrm{CO}_{2}$ of $25-50 \%$ [1-2]. Methane fermentation can be divided into four stages [1]:

- hydrolysis, in which enzymes produced by hydrolytic bacteria break down proteins, lipids and carbohydrates into amino acids, long chain fatty acids and sugars,

- acidification in which acetic acid-forming compounds from hydrolysis produced volatile fatty acids (butyric, acetic and propionic acids) and carbon dioxide, hydrogen and ethanol,

- acetogenesis, where acetic acid, hydrogen and carbon dioxide are formed with the formation of acidic bacteria,

- methanogenesis, in which acetic acid and hydrogen produce the final product, biogas.

During methane fermentation in a typical agricultural biogas plant substrates, such as rapeseed straw, hay, maize straw, or ligno-cellulose substrates, are slightly decomposed. This is because these substrates consist of lignin that surrounds cellulose and hemicellulose. This structure greatly limits their ability to biodegrade. Cellulose and hemicellulose are readily degraded by anaerobic bacteria and can be converted to methane [2]. As lignin is not digested by anaerobic bacteria in the anaerobic digestion process, solutions are being sought to develop methods of efficient pre-treatment of biomass fragmentation, thereby contributing to the ease of hydrolysis in the fermentation process. This is a technical problem, and therefore methods are sought that will lead to the release of cellulose and hemicellulose to achieve higher yields and quality of biogas produced [1].

There are many options [3] for anaerobic digestion, but the most important is the choice of the fermentation mode [4] Figure 1.

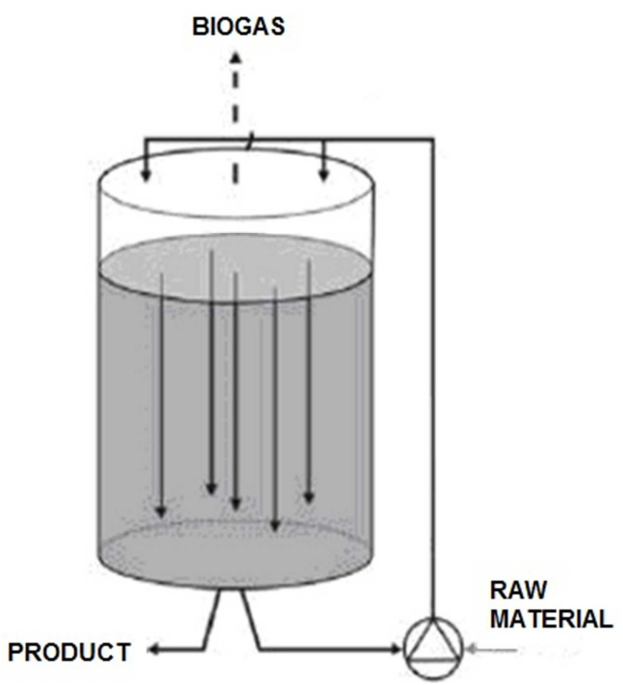

(a) 


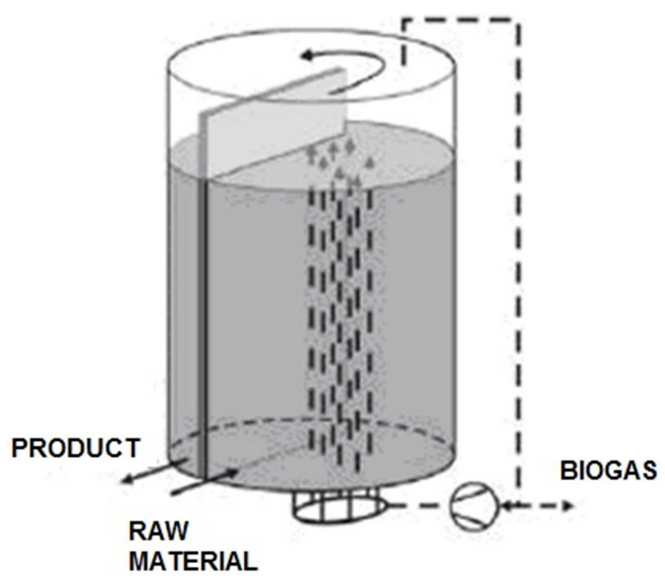

(b)

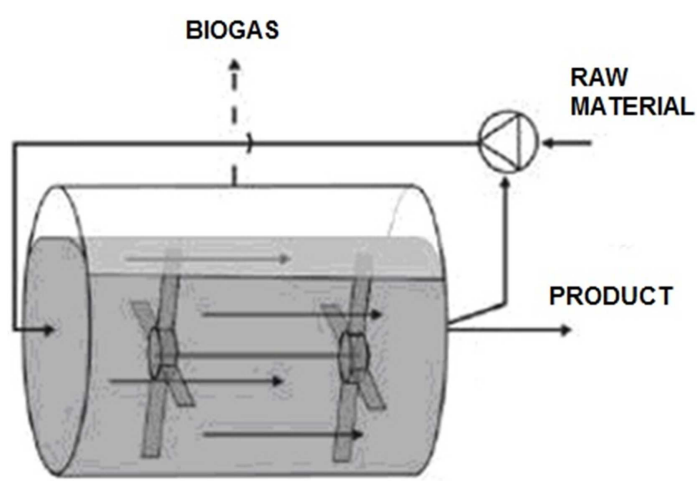

(c)

Figure 1. Examples of the location of the utilization of waste by the system [4]: a) Dranco, b) Valorga, c) Kompogas.

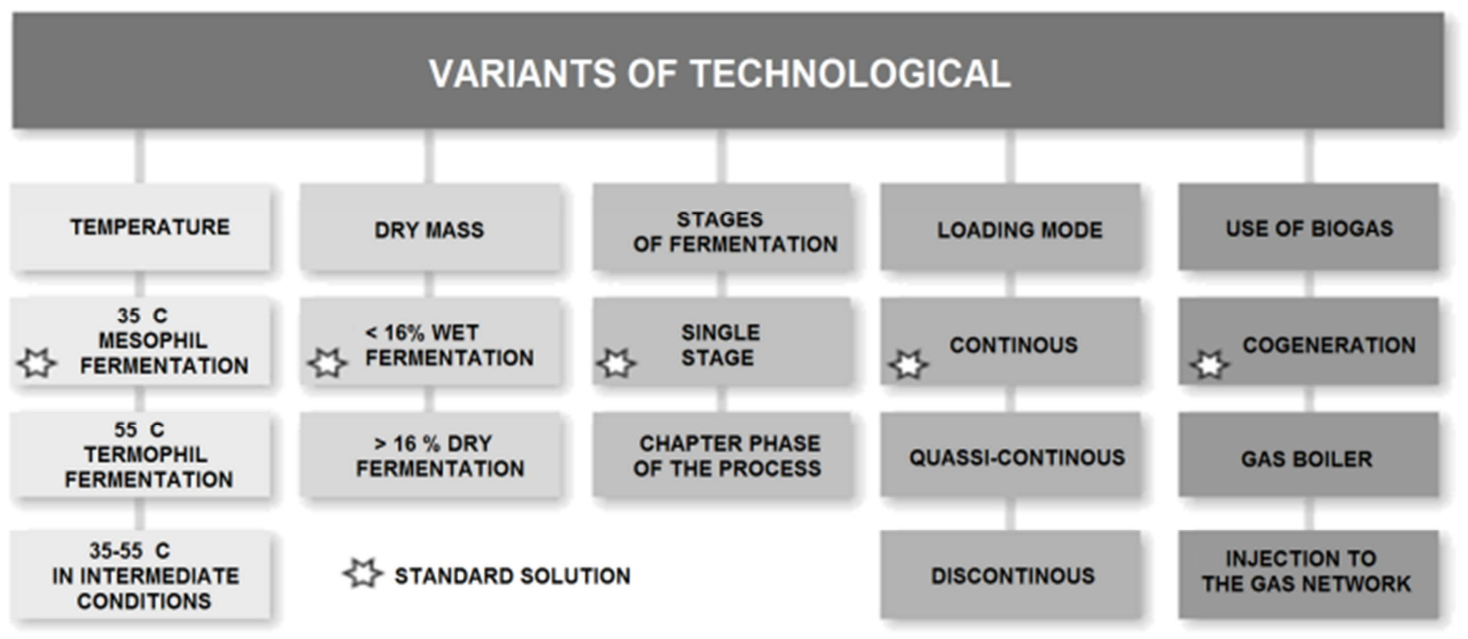

Figure 2. Variants of technological construction of agricultural biogas plant [3].

The biogas plant can be equipped with one or more fermentation chambers, depending on the technology used. The chambers may be concrete or steel, equipped with a heating system, must be adequately insulated to allow access to the interior in case of failure or maintenance or repair work. The chambers are most often built on the surface of the ground, and are less likely to be partially submerged. It is also possible to completely recess chambers in the ground, which allows for better thermal insulation, but hinders access to its interior and auxiliary devices [5].

The current state of knowledge about the operation of agricultural biogas plants concerns relatively large installations with power from $250 \mathrm{~kW}$ to $3 \mathrm{MW}$ and relatively uncomplicated technology of biomass production (Figure 2) mainly on arable land.

Numerous scientific reports [6-13] refer to standard trials of anaerobic digestion of substrates and residues from postproduction residues and by-products generated within farms and in rural areas. Publications in this field provide insights into the biogas efficiency of the different biomass used for biogas [14-16]. Only the publication available contains the results of studies on the preparation of specific fermentation mixtures from available substrates and co-substrates with already known biogas yield [17]. Such research is conducted at the Institute of Technology and Natural Sciences in Poznan [17-18]. Few studies investigate interactions of inhibitors and studies on the optimization of fermentation mixtures, Hard substrates that either can inhibit the fermentation process (eg legume seeds) or cause excessive hydrogen sulphide in the biogas (eg distillery) or are a source of odor emissions (eg onion waste) [1].

\section{Problem of Sanitation of Emerging Post-Production Residues}

Reduction of negative environmental effects of intensive livestock production requires the addition of additional plant and equipment to the ongoing production cycle, which will enable the current post-production residue to be sanitized. This process should be streamlined and one of the links in the food production process [19]. Pig slurry is most often produced on farms which have the capacity to manage the waste residues in the area of land used. These farms, apart from animals, properly adapted buildings and livestock buildings, are usually equipped with professionally constructed and operated slurry storage tanks. The capacity of these tanks, under the provisions in force, allow the 
storage of slurry by min. Four months. After this period and in the agricultural season of fertilization of crops, it is in a raw state (not fermented) exported to the fields. Its composition includes, among others. Large quantities of germination of weed seeds, parasite eggs and pathogenic microorganisms. Incorporation into the production cycle of the system allowing the entire slurry stream to be directed from the cowshed or piggybacking channels to the reactor in which the anaerobic fermentation takes place will allow for a biologically pure fertilizer. In this way, in addition to obtaining energy in the form of electricity and heat, it will be possible to use in fields of ecological and fertilizer value in the field. This installation will also meet the criteria for sustainable production in livestock farms [19].

\section{Mono-Substrate Flow Biogas Reactor}

The reactor (Figure 3a) was built on the basis of the patent specification - the exclusive rights number PL220074 [20]. At present, few companies offer biogas reactors suitable for the production of biogas from only one type of raw material slurry. Existing reactors, for the most part, provide for the use of a variety of substrates and substrate combinations, the role of which is to increase the efficiency of biogas production. The reactor (Figure $3 \mathrm{~b}$ ) enables the methane fermentation of raw slurry as monosubstrate or with the addition of other liquid components. It is also possible to use additives to increase the efficiency of the process in the form of properly shredded mash. Various forms of interior filling have been used in the reactor construction to increase the surface area where microorganisms responsible for methane fermentation can be deposited.

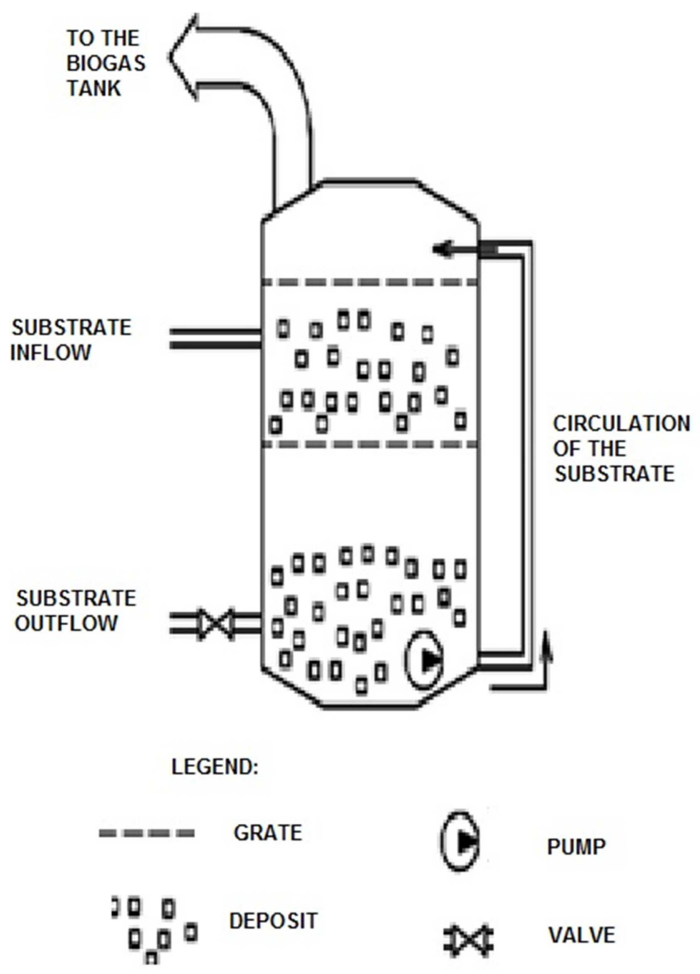

(a)

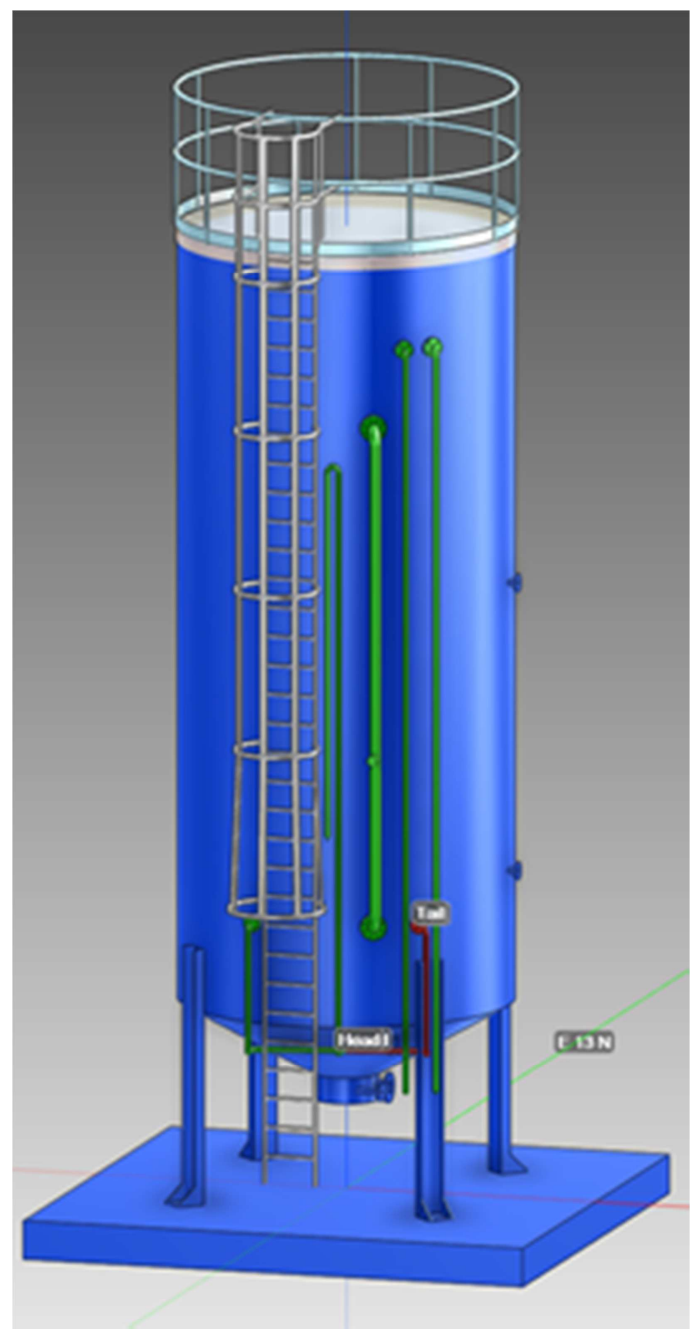

(b)

Figure 3. Flow mono-substrate reactor for methane fermentation of liquid manure: a) schematic idea [21], b) visualization of the reactor according to the AVEVA software - own model.

The developed system enables the construction of installations with a power of $3 \div 40 \mathrm{~kW}$ - a pilot installation with an active capacity of $15 \mathrm{~m}^{3}$ of fermenter was located in a farm with 1100 fatteners (pigs) kept in a grate system Figure 4. Pig slurry circulates between the upper and lower parts of the reactor at a frequency adjusted to the actual dry matter content. The fermentation process can take $10 \div 12$ days. It is therefore a universal reactor in which the parameters of the anaerobic digestion process can be adjusted to the methano-creative value of a particular pig slurry [19].

The "gas path" system is a set of equipment and installation equipment - used to transfer, treat, store and use biogas. In this layout you can distinguish:

- Biogas circulation at the fermenter, tubular coupler connecting the top of the fermenter to the bottom; Used to squeeze a part of biogas produced by fermentation mixture. The circulation takes place in the automatic cycle as a function of time - the pump pumps the freshly biogas through the substrate several times a day; When the filling and drain systems are off. 


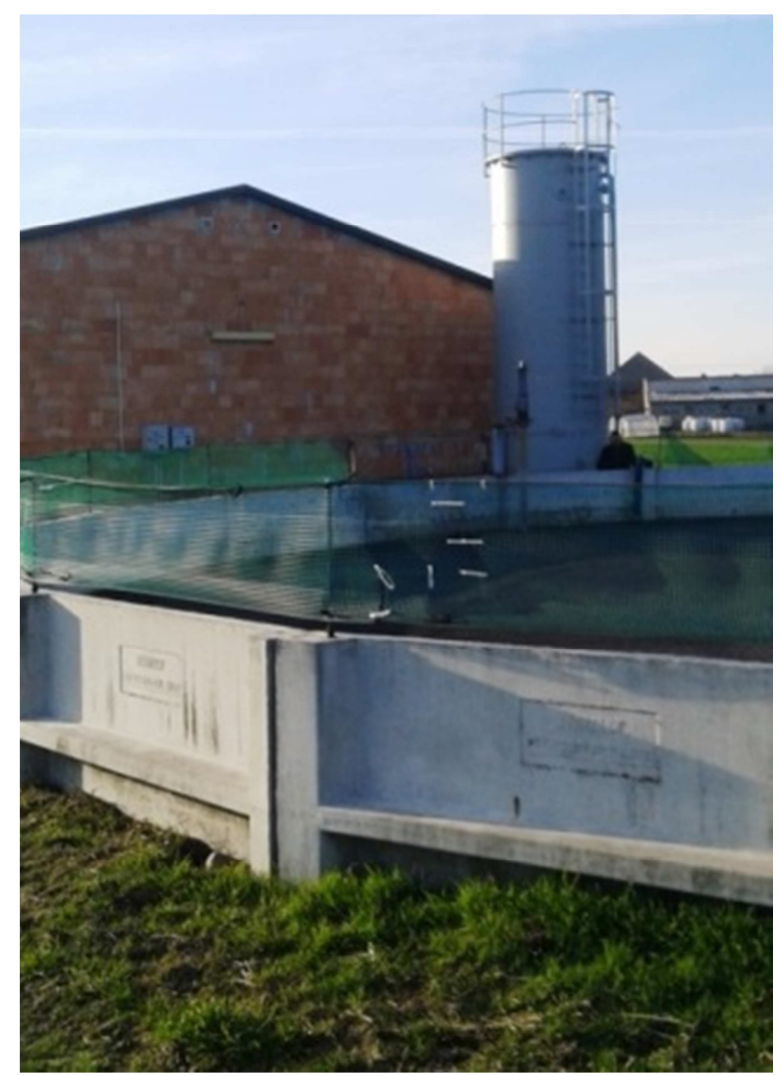

Figure 4. View of a mono-substrate reactor on a farm holding 1100 pigs. (Photo by Grzegorz Walowski).

- Biogas treatment, biogas desulfurizer and biogas trapped by a pipe coupler (from fermenter to biogas tank) with equipment. The system is equipped (at the input) with an unmanaged gas analyzer and an analyzer that controls the chemical composition of the gas at the outlet. The gas analyzer mainly informs about the concentration of hydrogen sulphide in the biogas, and its indications can be controlled on the display or used to activate the "visual-sounding" signal, or control the operation of the adsorber unit. Regeneration of the deposit takes place after the loss of biogas purge capacity from harmful admixtures. Depending on the amount, type of adsorber used, and the efficiency of the system, this is about 1 time per $\sim 3$ months and (in this case) the process is disabled from the automatic control cycle.

- The gas meter indicates the amount of biogas produced and treated. Other measuring devices (pressure gauge, flow meter, thermometer) are used to determine the quality of the adsorber operating parameters. - Biogas tank: Used to collect biogas produced, equipped with a liquid fuse that protects the tank from exceeding the maximum allowable pressure inside the tank and the valve used to discharge the condensate. The liquid fuse is characterized by a certain opening pressure (related to the structural strength of the gas tank) and is made according to a design that prevents the flame from entering the installation. At the fuse outlet, the final flame deflector flame was mounted - protected against precipitation.

- The biogas system of the cogeneration unit is responsible for sending the biogas, with the specified parameters, to the reception equipment. Safety features include a filter and a flame breaker. Treated biogas is collected from the tank with the blower and fed to a cogeneration unit. In case of switching off or failure of the co-generator, the pressure sensor will show a pressure increase and send a control signal to the automation element controlling the biogas flow control valve.

The research methodology is concerned with aspects of the physicochemical analysis of the charge, reactor technical parameters, methane fermentation process parameters, cogenerator energy efficiency, quantitative and qualitative analysis of generated biogas and economic analysis of technology. An analytical data algorithm was developed to calculate the capacity of a mono-substrate flow reactor for methane pig slurry fermentation, which will be used to analyze the test results.

\section{A Method of Adapting a Cogeneration Unit}

The semi off grid system does not plan to sell power to the grid, but it is bound to it. Such a system can be effective because it ensures continuity of energy supply (in the case of insufficient own supply or system failure) from the network and at the same time does not introduce energy into the National Power System so that its installation does not require problematic permits for connection to the power grid, Which until now was one of the biggest administrative barriers for the development of RES systems in the country (in 2013 operators themselves refused to connect almost 10 GW generation sources). Nowadays it is difficult to judge which decisions will be taken by investors. With installations up to $40 \mathrm{kWe}$, the possibility of selling energy to the grid at favorable prices will probably be used. For larger installations or in areas with poor infrastructure, networking is possible.

Large cogeneration units can operate for more than 8,000 hours a year, and maintenance and oil change are normally performed during the aggregate operation. For low power units, frequent and longer maintenance intervals are required. It must be assumed that 4 times a year the aggregate will be excluded from work. A number of hours worked will not be much higher than 6000 hours. It is, therefore, necessary to anticipate the need to consume additional energy for the sustained life processes of the microflora inside the reactor. For this reason, it is envisaged to use cogeneration for a dual fuel engine. The cogeneration unit was adapted for incineration of gaseous and liquid biofuels in accordance with the exclusive patent number 217369 [22]. The developed solution will thus introduce the use of multi-fuel cogeneration units, where other conventional energy sources, not methane fermented, can also be used. Energy sources will increase system security and comfort and provide greater reliability as energy generation will also be possible if biotechnological processes are temporarily interrupted or their efficiency is insufficient. 


\section{Conclusions}

Reducing negative environmental effects of intensive livestock production requires incorporating additional plant and equipment into the production cycle, enabling the production cycle to be closed to a hermetic space that isolates animals from the natural environment. This can be accomplished through the ongoing sanitation of manure and the various ways of utilizing and cleaning exhausted air from the livestock premises. These processes should be streamlined and be one of the links in the food production process. The need for such an approach to the construction and operation of livestock facilities is a result of frequent conflicts between villagers and farmers developing livestock production.

Incorporation into the production cycle of an installation for directing the entire flow of slurry from the channels under the grate barn or pigsty to operating as a flow reactor, which will occur methane fermentation, allows for pure biological fertilizer. Thus, in addition to its energy in the form of electricity and heat, an application will be possible in the field of value ecologically and dropwise-creative fertilizer. This setup will also meet the criteria for the implementation of sustainable production in farms engaged in livestock production.

The use of the project results will be possible and profitable in economic life. The project envisages the creation of complete, comprehensive, durable, cheap to use and cost-effective solutions, which will reduce the cost of operation of farms. The final products of the project are: a mono-substrate flow biogas reactor, a prosumer biogas plant with an output up to $40 \mathrm{~kW}$. Taking into account the current shape of the RES Act [23], the offered biogas products (40 $\mathrm{kW}$ ) will be cost-effective to implement. The fact that they will be adapted to the use of substrates that will function as post-production residues in the holdings will result in a simultaneous reduction in the operating costs of those holdings (no need to recycle), as well as additional electricity generation and additional heat generation benefits. And hygienic, valuable utilization of waste that can be used for fertilizer or heating purposes. Thermal and hygienically valuable digestible substances that can be used for fertilization or heating purposes.

\section{Acknowledgements}

The study conducted as part of the project financed by the National Centre for Research and Development conducted in the BIOSTRATEG program, contract No BIOSTRATEG1/269056/5/NCBR/2015 dated 11 August 2015.

\section{References}

[1] G. Wałowski, B. Łaska-Zieja, Ł. Aleszczyk, A. Myczko, Przem. Chem., 95, 9, 1788 (2016).

[2] E. Klimiuk, M. Pawłowska, T. Pokój, Biopaliwa. Technologie dla zrównoważonego rozwoju, (Biofuels. Technologies for sustainable development), Ed. Scientific PWN, Warsaw 154 (2012).

[3] A. Oniszk-Popławska, M. Matyka, Kompleksowa ocena uwarunkowań $w$ zakresie produkcji biogazu $w$ województwie lubelskim (Comprehensive assessment of biogas production conditions in lubelskie voivodship), Final report on field research, Regional Economic Management System, 2012.

[4] A. Jędrczak, Przegl. Komunalny, 6 (2001).

[5] A. Kowalczyk-Juśko, Biogazownie szansa dla rolnictwa $i$ środowiska, (Biogas is an opportunity for agriculture and the environment), editor A. Grzybek, Ed. Foundation for the Development of Polish Agriculture, Publication prepared under the Central Secretariat of the National Rural Network's Action Plan for the years 2007-2013, ISBN 978-83-937363-00 .

[6] A. Pilarska, K. Pilarski, A. Ryniecki, Wykorzystanie fermentacji metanowej do zagospodarowania wybranych produktów odpadowych przemystu spożywczego. (Utilization of methane fermentation for the development of selected food waste products) Nauki Inżynierskie i Technologie, 2014, 4 (15), 100-111.

[7] A. Grosser, M. Worwąg, E. Neczaj, A. Grobelak, Pótciagła kofermentacja osadów ściekowych $i$ odpadów thuszczowych pochodzenia roślinnego. (Semi-co-sourcing of sewage sludge and vegetable waste fat.) Środkowo-Pomorskie Towarzystwo Naukowe Ochrony Środowiska, Rocznik Ochrona Środowiska, 2013, Vol. 1 5, ISSN 1506-218X, 2108-2125.

[8] J. Sikora, Badanie efektywności produkcji biogazu z frakcji organicznej odpadów komunalnych zmieszanej z biomasa pochodzenia rolniczego. (Study on the efficiency of biogas production from organic fraction of municipal waste mixed with biomass of agricultural origin) Infrastruktura i Ekologia Terenów Wiejskich, 2012, 2/IV, 89-98.

[9] J. Sikora, A. Tomal, Wyznaczenie potencjatu energetycznego biogazu w wybranym gospodarstwie rolnym. (Determining the energy potential of biogas in a selected farm) Infrastruktura $\mathrm{i}$ ekologia terenów wiejskich, PAN, Oddział w Krakowie, Komisja Technicznej Infrastruktury Wsi, Nr III/2/2016, 971982, DOI:

http://dx.medra.org/10.14597/infraeco.2016.3.2.071.

[10] E. Głodek, Raport z projektu unijnego POKL. 08.02.01-16028/09 Źródła Energii Opolszczyzny - promocja, technologie wsparcie, wdrożenie. Instytut Ceramiki i Materiałów Budowlanych, Oddział Inżynierii Materiałowej, Procesowej i Środowiska, Opole marzec $2010 \mathrm{r}$.

[11] E. den Boer, R. Szpadt, Materiały konferencyjne Politechnika Wrocławska, Biogazownie szansą dla rolnictwa i środowiska, Dolnośląski Ośrodek Doradztwa Rolniczego we Wrocławiu 24 października $2013 \mathrm{r}$.

[12] J. Bień, Osady ściekowe. Teoria i praktyka, (Sewage sludge. Theory and practice), Wyd. Politechnika Częstochowska, 2007,312 .

[13] A. Olesienkiewicz, Czysta Energia (Pure energy), 2010, 5, 22.

[14] J. Karłowski, A. Kliber, A. Myczko, R. Golimowska, R. Myczko, Mat. IV Conf. Polish Agronomic Society, "Agronomy in the sustainable development of modern agriculture", Warsaw, 5-7, 104 (September 2011). 
[15] W. Romaniuk, A. Głaszczka, K. Biskupska, Analiza rozwiazań instalacji biogazowych dla gospodarstw rodzinnych $i$ farmerskich. (Analysis of biogas installation solutions for family and farm households) Inżynieria $\mathrm{w}$ rolnictwie, Monografie nr 9, Falenty 2012, wyd. ITP.

[16] W. Czekała, J. Kaniewski, Perspektywy rozwoju biogazowni na terenach wiejskich województwa ślaskiego. (Prospects for the development of biogas plants in the rural areas of the Silesian province) Wyd. Akademia Słońca Krzysztof Frąszczak, Poznań 2015, ISBN 978-83944103-0-8.

[17] A. Myczko, R. Myczko, T. Kołodziejczyk, R. Golimowska, J. lenarczyk, Z. Janas, A. Kliber, J. Karłowski, M. Dolska, Budowa i eksploatacja biogazowni rolniczych (Construction and operation of agricultural biogas plants,), editor A. Myczko, Ed. ITP (financed by the European Agricultural Fund), Warsaw-Poznań, 137 (2011).

[18] T. Kołodziejczyk, R. Myczko, A. Myczko, Ciepłownictwo, Ogrzewanictwo, Wentylacja, 42, nr 9, 360 (2011).

[19] G. Wałowski, A. Myczko, G. Filipczak, Przem. Chem., 96, 3, 580-591 (2017) DOI:10.15199/62.2017.3.19.

[20] A. Myczko, R. Myczko, R. Szulc, L. Tupalski: Reaktor do metanowej fermentacji gnojowicy (Reactor for methane fermentation of slurry), Patent Specification PL 220074 B1, UPRP Warsaw 2015.

[21] A. Myczko, T. Kołodziejczyk, R. Sawiński, R. Myczko, Ł. Aleszczyk, B. Łaska-Zieja, G. Wałowski, E. WrzesińskaJędrusiak, Koncepcje matych biogazowni do przerobu rolniczych pozostatości poprodukcyjnych (Concepts of small biogas plants for the processing of agricultural postproduction residues), Chapter of monographs edited by Marian Lipiński and Jacek Przybyła "Current problems of engineering of biosystems 2017". Ed. University of Life Sciences in Poznan, Poznan 2017, 251-266, ISBN 978-837160-859-9.

[22] W. Golimowski, A. Kliber, R. Szulc, R. Golimowska, Generator energii cieplnej i elektrycznej zasilany biomasą pochodzenia zwierzęcego (Generator of heat and electricity powered by biomass of animal origin), Patent Specification PL 217369 B1, UPRP Warszawa 2014.

[23] A. Myczko, A. Kliber, I. Tupalski, Najnowsze osiagnięcia z zakresu OZE wraz z przedstawieniem barier we wdrażaniu wyników badań do praktyki gospodarczej (Recent achievements in OZE field with presentation of barriers in the implementation of research results to economic practice), editor B. Mickiewicz, Koszalin 2012. 